\title{
Cesium Removal from Simulated SRS High-Level Waste Using Crystalline Silicotitanate
}

by

D. D. Walker

Westinghouse Savannah River Company

Savannah River Site

Aiken, South Carolina 29808

W. D. King

D. P. Diprete

L. L. Tovo

D. T. Hobbs

W. R. Wilmarth

A document prepared for at, , from - .

DOE Contract No. DE-AC09-96SR18500

This paper was prepared in connection with work done under the above contract number with the U.S. Department of Energy. By acceptance of this paper, the publisher and/or recipient acknowledges the U.S. Government's right to retain a nonexclusive, royalty-free license in and to any copyright covering this paper, along with the right to reproduce and to authorize others to reproduce all or part of the copyrighted paper. 


\section{DISCLAIMER}

This report was prepared as an account of work sponsored by an agency of the United States Government. Neither the United States Government nor any agency thereof, nor any of their employees, makes any warranty, express or implied, or assumes any legal liability or responsibility for the accuracy, completeness, or usefulness of any information, apparatus, product, or process disclosed, or represents that its use would not infringe privately owned rights. Reference herein to any specific commercial product, process, or service by trade name, trademark, manufacturer, or otherwise does not necessarily constitute or imply its endorsement, recommendation, or favoring by the United States Government or any agency thereof. The views and opinions of authors expressed herein do not necessarily state or reflect those of the United States Government or any agency thereof.

This report has been reproduced directly from the best available copy.

Available to DOE and DOE contractors from the Office of Scientific and Technical Information, P.O. Box 62, Oak Ridge, TN 37831; prices available from (615) 576-8401.

Available to the public from the National Technical Information Service, U.S. Department of Commerce, 5285 Port Royal Road, Springfield, VA 22161. 


\section{DISCLAIMER}

Portions of this document may be illegible in electronic image products. Images are produced from the best available original document. 
WSRC-TR-98-00344, Rev. 1

Keywords: Waste processing, ion exchange

Retention: Permanent

\section{CESIUM REMOVAL FROM SIMULATED SRS HIGH-LEVEL WASTE USING CRYSTALLINE SILICOTITANATE}

D. D. Walker

W. D. King

D. P. Diprete

L. L. Tovo

D. T. Hobbs

W. L. Wilmarth

Publication Date: October 16, 1998

Westinghouse Savannah River Company

Savannah River Technology Center

A iken, SC 29808

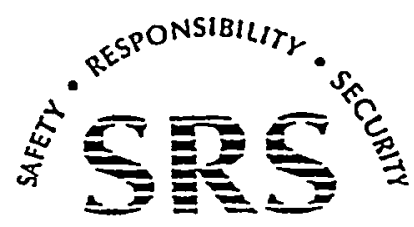


Cesium Removal from Simulated SRS High-Level Waste Using Crystalline Silicotitanate

\section{Authors}

Garrelk. Cuelber iol 16198

D. D. Walker, Waste Processing Technology Date

Crleiem D. King

$10 / 19 / 98$

W. D. King, Waste Processing Technology

Date

\section{Dais QRT}

$10 / 19 / 98$

D. P. Diprete, Analytical Development

Date

Taven d. Thuo

$10-20-98$

L. L. Tovo, Analytical Development

Date

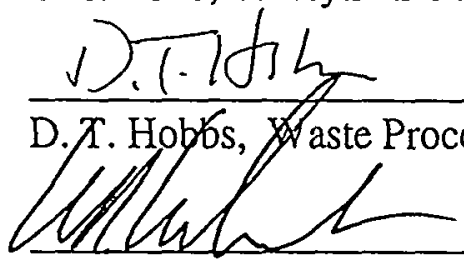

W. E. Wilmarth, Waste Processing Technology

$10 / 19 / 98$

Date

$10 / 14 / 48$

Date

Design Check

Buchar Pperin $10 / 20 / 98$

M. R. Poirier, Waste Processing Technology

Date

(per Manual E7, Procedure 2.40)

Approvals

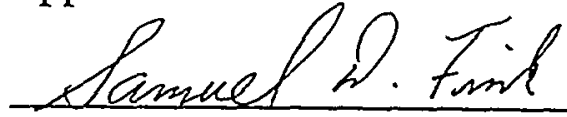

$$
10-19-98
$$

S. D. Fink, Level 4 Manager, Waste Processing Technology

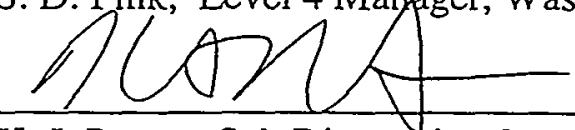

K. J. Rueter, Salt Disposition Systems Engineering Team

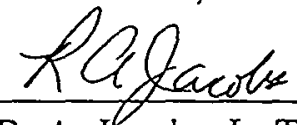

R. A. Jacobs, In-Tank Precipitation Flow Sheet Team

Date

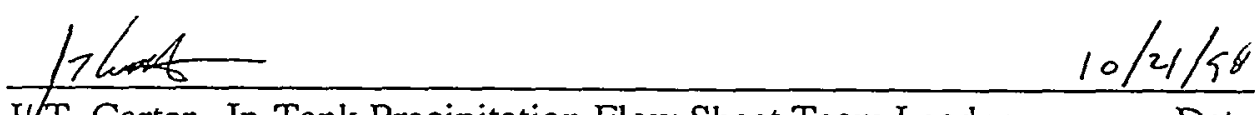

JVT. Carter, In-Tank Precipitation Flow Sheet Team Leader

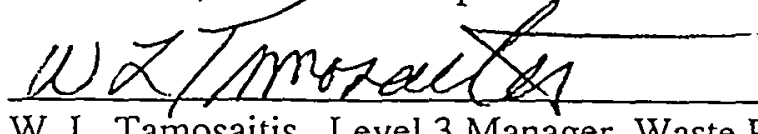

W. L. Tamosaitis, Level 3 Manager, Waste Processing Technoldgy ${ }^{\text {Date }}$

Date

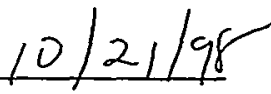

Date

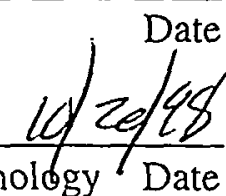




\section{CONTENTS}

SUMMARY..............................................................................................

INTRODUCTION................................................................................

RESULTS AND DISCUSSION.................................... 5

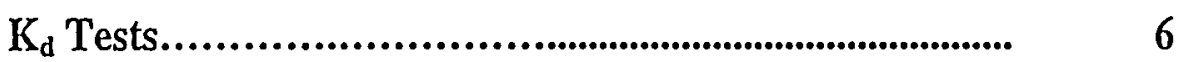

Column Tests....................................................................... 10

ACKNOWLEDGMENTS.......................................... 12

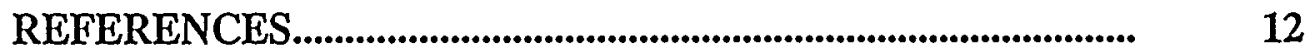

APPENDIX A. Oak Ridge National Laboratory Report on $\mathbf{K}_{\mathbf{d}}$

Measurements.............................................................

APPENDIX B: Texas A\&M Predictions of Column

Performance........................................................ 19

APPENDIX C: Experimental.............................................................. 22 


\title{
CESIUM REMOVAL FROM SIMULATED SRS HIGH-LEVEL WASTE USING CRYSTALLINE SILICOTITANATE
}

\author{
By D. D. WALKER
}

\section{SUMMARY}

This study measured the adsorption of cesium from simulated Savannah River Site liquid waste onto crystalline silicotitanate (CST) in equilibrium $\left(\mathrm{K}_{d}\right)$ and ion exchange column tests. The tests used IONSIV® IE-911 (UOP LLC, Molecular Sieves Division, Des Planes, IL), the engineered form of CST. The results of the tests show good agreement with predictions from models used by Professor R. G. Anthony of Texas A\&M University. The following summarize the results.

- Cesium adsorption in static $\left(\mathrm{K}_{\mathrm{d}}\right)$ tests matched predictions from a model developed at Texas A\&M for the powder form of CST.

- Measured $\mathrm{K}_{d} \mathrm{~s}$ averaged about $10 \%$ below predicted values.

- At $23{ }^{\circ} \mathrm{C}, \mathrm{K}_{\mathrm{d}} \mathrm{S}$ varied between 1560 and $2840 \mathrm{~mL} / \mathrm{g}$ depending on the composition of the salt solution.

- Measured trends in $\mathrm{K}_{d} \mathrm{~s}$ due to changes in solution composition agreed with trends predicted by the model.

- Measured $\mathrm{K}_{d} \mathrm{~s}$ in low sodium salt solution (4M) and at elevated temperature $\left(45^{\circ} \mathrm{C}\right)$ showed less agreement with the model.

- Differences between production batches were small $(<15 \%)$.

- The $\mathrm{K}_{d}$ for the developmental sample (38B) used in previous testing was significantly lower $(-27 \%)$ than the average for production batches. This difference accounts for the "dilution factor" derived from previous tests.

- Cesium removal in two column tests at rapid feed rates (i.e., superficial velocities of 0.98 and $4.1 \mathrm{~cm} / \mathrm{min}$ ) in the range of proposed process conditions closely matched predictions from Texas A\&M.

- This result implies that current models will predict process column performance without major adjustments to the models.

- Cesium removal in a slow feed rate (i.e., superficial velocity of $0.27 \mathrm{~cm} / \mathrm{min}$ ) column test demonstrated better cesium removal than predicted by the Texas A\&M model.

- Cesium breakthrough remained less than $0.0025 \%$ for 300 column volumes. The model predicted cesium would breakthrough at 103 column volumes. 


\section{INTRODUCTION}

Non-elutable ion exchange is one of the alternatives for removing cesium from Savannah River Site (SRS) soluble radioactive waste.' Crystalline silicotitanate (CST) particles are the reference ion exchange medium for the process. Previous studies measured cesium distribution on CST samples in powder form ${ }^{2}$ and in the engineered form ${ }^{3}$ in SRS simulated wastes. The distribution coefficients $\left(K_{d} s\right)$ measured previously with the engineered form of CST proved consistently smaller than predicted from a Texas A\&M model based on the powdered form of CST. ${ }^{4-5}$ This is not unexpected since the engineered form contains an inert binder in addition to the powdered form of CST. No previous column experiments examined using CST in SRS wastes. Therefore, Savannah River Technology Center (SRTC) began this study to determine the performance of the IONSIV $\mathbb{I E}-911$ production batches in SRS waste and quantify the discrepancy between measured $K_{d} S$ and predictions from the Texas A\&M model. Additional $K_{d}$ tests started at Oak Ridge National Laboratory (ORNL) to supplement the SRTC work. In addition, column tests with production batches of IONSIV® IE-911 in SRS simulated waste initiated at SRTC.

This work partially fulfills a request from P. L. Rutland, Technical Task Request, "CST Ion Exchange - Salt Team Phase 3 Evaluation," \#HLE-TAR-98060, July 14, 1998. The work complies with the following plan: D. D. Walker, "Scoping Tests for Crystalline Silicotitanate Flowsheet," WSRC-RP-98-00732, Rev.0, August 21, 1998.

\section{RESULTS AND DISCUSSION}

Researchers investigated both equilibrium and dynamic aspects of cesium adsorption on CST particles. The tests occurred at SRTC and ORNL. Appendix A summarizes the ORNL results. Appendix C contains the experimental details for the SRTC tests.

The equilibrium measurements ( $\mathrm{K}_{\mathrm{d}}$ tests) measured the performance differences between IONSIV $® \mathbb{E}-911$ production batches as well as the variance in performance with different waste . compositions. Column tests at different feed rates measured kinetic aspects of cesium absorption at superficial velocities in the range proposed for full-scale column operations and demonstrated that large cesium decontamination factors result with CST.

The salt solutions used in these tests simulate the variety of compositions expected in processing the inventory of SRS soluble waste (Table D). ${ }^{1}$ The major difference in the three waste varieties involves the ratio of hydroxide to nitrate ions. Average waste represents the hypothetical feed composition assuming dissolution of all of the current inventory of salt cake and blending with the total supernate inventory. High hydroxide waste represents partial blending of supernate with dissolved salt cake and reflects the high hydroxide content of the supernates in the waste tanks. High nitrate waste represents the feed composition of dissolved salt cake without blending of supernates. 
TABLE I. Composition of Simulated Waste Solutions

\begin{tabular}{|c|c|c|c|}
\hline \multirow[b]{2}{*}{ Component } & \multicolumn{3}{|c|}{ Concentration (molar) } \\
\hline & Average & High $\mathrm{OH}^{-}$ & ${\mathrm{High} \mathrm{NO}_{3}}_{3}$ \\
\hline $\mathrm{Na}^{+}$ & 5.6 & $\overline{5.6}$ & 5.6 \\
\hline $\mathrm{K}^{+}$ & 0.015 & 0.030 & 0.0041 \\
\hline $\mathrm{Cs}^{+}$ & 0.00014 & 0.00037 & 0.00014 \\
\hline $\mathrm{OH}^{-}$ & 1.91 & 3.05 & 1.17 \\
\hline $\mathrm{NO}_{3}^{-}$ & 2.14 & 1.10 & 2.84 \\
\hline $\mathrm{NO}_{2}^{-}$ & 0.52 & 0.74 & 0.37 \\
\hline $\mathrm{AlO}_{2}^{-}$ & 0.31 & 0.27 & 0.32 \\
\hline $\mathrm{CO}_{3}{ }^{2-}$ & 0.16 & 0.17 & 0.16 \\
\hline $\mathrm{SO}_{4}{ }^{2-}$ & 0.15 & 0.30 & 0.22 \\
\hline $\mathrm{Cl}^{-}$ & 0.025 & 0.010 & 0.040 \\
\hline $\mathrm{F}$ & 0.032 & 0.010 & 0.050 \\
\hline $\mathrm{PO}_{4}^{3-}$ & 0.010 & 0.008 & 0.010 \\
\hline $\mathrm{C}_{2} \mathrm{O}_{4}{ }^{2-}$ & 0.008 & 0.008 & 0.008 \\
\hline $\mathrm{SiO}_{3}{ }^{2-}$ & 0.004 & 0.004 & 0.004 \\
\hline $\mathrm{MoO}_{4}{ }^{2-}$ & 0.0002 & 0.0002 & 0.0002 \\
\hline
\end{tabular}

$\mathrm{K}_{\mathrm{d}}$ Tests

Consistent and reproducible $K_{d}$ values prove difficult to obtain and require careful attention to the sample preparation and experimental procedure. Factors that may contribute to the scatter in the measurements include water adsorption by IONSIVß IE-911 during storage and handling, differences in cesium adsorption properties between production batches, CST fines adhering to the larger engineered particles, and differences in laboratory protocols for measuring $K_{d} s$. The controlled tests described below investigated these factors.

A typical test shakes a portion of CST in a fixed volume of salt solution until equilibrium occurs. Personnel measure initial $\left(\mathrm{C}_{0}\right)$ and final $(\mathrm{C})$ concentrations of cesium and calculate the distribution coefficient $\left(\mathrm{K}_{d}\right)$ from the following equation.

$K_{d}=\left[\left(C_{0} / C\right)-1\right] \mathrm{V} / \mathrm{m}$

where $\mathrm{V}$ is the volume of solution and $m$ is the mass of CST.

The mass of CST used includes a correction for the water lost on drying as measured in a separate experiment. 


\section{Water Content of Production Batches}

Water content of a developmental sample (38B) and three production batches varied between 4 and $13 \mathrm{wt} \%$. Table II lists measurements of weight loss on drying at $105^{\circ} \mathrm{C}$ for as-received IONSIV(B) IE-911. Weight loss presumably results from vaporization of water retained in the macropores of the IONSIV $\mathbb{E}$ IE-911. The water content of the particles will vary depending on the air humidity and exposure. In some cases, particularly Batch 0002, the water content significantly affects the calculated $\mathrm{K}_{d} \mathrm{~s}$. To eliminate this source of variability when calculating $K_{d} s$, researchers in both laboratories corrected the weight of IONSIV® IE-911 particles for the measured water content.

\section{Evaluation of IONSIV@IE-911 Production Batches}

SRTC and ORNL researchers measured $\mathrm{K}_{\mathrm{d}} \mathrm{S}$ on three production batches and on the developmental sample in average SRS waste simulant. No sample of production Batch 3 existed in the as-received condition. Table III lists the results. The data indicates good agreement between ORNL and SRTC measurements (i.e., compare the two laboratories for Batch 4) and no significant differences among the three production batches. However, the developmental sample (38B) appears to have a significantly lower $\mathrm{K}_{\mathrm{d}}$ compared to the production batches.

The SRTC researchers further investigated the developmental sample to confirm the low $\mathrm{K}_{\mathbf{d}}$. McCabe $^{3}$ reported a $\mathrm{K}_{d}$ of $1500( \pm 170)$ using a salt solution with composition similar to the high hydroxide simulant listed in Table I. Upon repeating the $\mathrm{K}_{d}$ measurements in the McCabe simulant, the Batch $38 \mathrm{~B} \mathrm{~K} \mathrm{~K}_{d}(1370 \mathrm{~mL} / \mathrm{g})$ again proved significantly smaller than the Batch $2 \mathrm{~K}_{d}$ $(1900 \mathrm{~mL} / \mathrm{g})$. We conclude a significant difference exists in cesium absorption properties between the two batches. The difference may result from differences in the amount or type of binder used to form the engineered particles.

TABLE II. Water Content in IONSIY® IE-911 Samples.

$\begin{array}{ccc}\frac{\text { Batch* }}{38 \mathrm{~B}} & \text { Water Content }(\text { wt } \%) & \frac{\text { Laboratory }}{\text { SRTC }} \\ 2 & 6.9 & \text { SRTC } \\ 4 & 13.0 & \text { SRTC } \\ & 3.0 & \\ 4 & 4.79 & \text { ORNL } \\ 1 & 5.46 & \text { ORNL }\end{array}$

*The complete UOP lot number for the preproduction batch (Batch 38B) is IE-910 07398-38B. The complete lot number for production batches begins with "99909681000" and ends with 1,2, 3 , or 4 . For simplicity, the listing delete the leading portions of the lot numbers. 
TABLE III. Comparison of As-Received Particles

$\begin{array}{cll}\text { Batch } & \begin{array}{c}\mathbf{K}_{\mathbf{d}}^{*} \\ (\mathbf{m L} / \mathbf{g})\end{array} & \text { Source** } \\ 1 & 2250 & \text { ORNL } \\ 2 & 1940,2240 & \text { SRTC } \\ 4 & 1970 & \text { SRTC } \\ 4 & 2150 & \text { ORNL } \\ \text { 38B } & & \\ & 1530 & \text { SRTC }\end{array}$

*Each entry represents the average of two measurements. Multiple entries for Batch 2 indicate duplicate measurements made at different times. Measurements used SRS average waste solution (Table I).

**Laboratory where measurements occurred.

\section{Effects of Particle Fines}

As-received IONSIV® IE-911 nominally contain particles of 30 to 60 mesh (600 to 200 micron), but washing the particles produces a cloudy solution presumably due to $<200$ micron fines. Column operations remove fines from ion exchange material to avoid problems such as plugging the screens holding the packing in the column or contamination of the effluent stream from fines passing through the screen. Testing examined whether fines present in as-received particles used in $\mathrm{K}_{\mathrm{d}}$ tests biased the $\mathrm{K}_{d}$ measurements relative to washed particles used in column tests. Table IV lists results of tests comparing as-received particles to particles after removal of fines. The ORNL researchers removed fines by sieving the larger particles while SRTC personnel removed fines by flushing upflow with water. In both laboratories, the particles with fines removed yielded smaller $K_{d} s$, although the differences (-3:6 and -13.9\%) may fall within the reproducibility of the measurements. However, the consistently lower value for particles with fines removed suggests a small effect.

TABLE IV. Effect of Fines on $\mathrm{K}_{\mathrm{d}} \mathrm{s}^{*}$

\begin{tabular}{|c|c|c|c|}
\hline Batch & Condition & $\begin{array}{c}\mathbf{K}_{\mathrm{d}} \\
(\mathrm{mL} / \mathrm{g})\end{array}$ & Source \\
\hline \multirow[t]{2}{*}{2} & as-received & 1940 & SRTC \\
\hline & fines-removed $* *$ & 1870 & SRTC \\
\hline
\end{tabular}

(Change: -3.6\%)

4

$\begin{array}{lll}\text { as-received } & 2149 & \text { ORNL } \\ \text { fines-removed } & \\ & 1850 & \text { ORNL }\end{array}$

(Change: $-13.9 \%$ )

* Measured in SRS average waste simulant at room temperature.

**The SRTC tests removed fines by flushing with water; ORNL tests removed fines by sieving. 
Accuracy of the Texas $A \& M K_{d}$ model for SRS waste compositions.

Researchers tested the accuracy of the Texas A\&M K $\mathrm{K}_{d}$ model by investigating the effects of feed type (i.e., ratio of hydroxide to nitrate), total salt concentration, potassium concentration, temperature, and cesium concentration (particularly at very low cesium concentrations).

Table IV lists the test matrix as well as the measured and predicted $\mathrm{K}_{d} \mathrm{~S}$.

Predictions and measurements agreed within $\pm 15 \%$ in all but two tests. Excluding the two outliers, the difference averages $-2 \%$. Including the outliers yields an average bias of $-8 \%$. Thus, agreement between predictions and measurements, on the average, appears quite good and reflects the experimental uncertainty. In most cases, the Texas A\&M model accurately predicts cesium adsorption behavior. The results of this investigation do not support a "dilution" factor between the model (based on powdered form of CST) and the engineered particles. The dilution factor derived from the work of $\mathrm{McCabe}$ apparently reflects the poorer performance of the developmental sample rather than a generic dilution by the inert binder.

Two measurements differed significantly from predictions: one with a solution of low salt concentration (i.e., $\mathrm{K}_{d}-23 \%$ relative to predicted) and one with average solution at the high temperature(i.e., $\mathrm{K}_{\mathrm{d}}-45 \%$ relative to predicted). Although Anthony stated the model loses accuracy at sodium concentrations below $1 \mathrm{molar}$, one expects a much smaller error than observed at $4 \mathrm{M}$. Review of the experiment did not reveal anything unusual. Resolution of this discrepancy requires further inquiry. The test at $45^{\circ} \mathrm{C}$ exceeds the temperature limit of the Texas A\& $\mathrm{M} \mathrm{K}_{\mathrm{d}}$ model capability (i.e., the computer model will not accept temperatures above $44^{\circ} \mathrm{C}$ ). The model needs additional experimental data at higher temperature to improve on these predictions.

TABLE V. Measured and Predicted Cesium $\mathrm{K}_{\mathrm{d}}{ }^{\prime} \mathrm{s}^{*}$

\begin{tabular}{|c|c|c|c|c|c|c|c|c|}
\hline Variable & Test & Waste type & $\begin{array}{l}{\left[\mathrm{Na}^{+}\right]} \\
(\mathrm{M})\end{array}$ & $\begin{array}{l}{\left[\mathrm{K}^{+}\right]} \\
(\mathrm{mM}) \\
\end{array}$ & $\begin{array}{l}{\left[\mathrm{Cs}^{+}\right]} \\
(\mathrm{mM}) \\
\end{array}$ & $\begin{array}{l}\text { Temp. } \\
\left({ }^{\circ} \mathrm{C}\right)\end{array}$ & $\begin{array}{r}\mathrm{K}_{\mathrm{d}} \\
\text { Measured }\end{array}$ & $\begin{array}{l}(\mathrm{mL} / \mathrm{g}) \\
\text { Predicted }\end{array}$ \\
\hline \multirow[t]{3}{*}{ Waste type } & 1 & Average & 5.6 & 15 & 0.14 & 22 & 1940 & 2230 \\
\hline & 2 & High $\mathrm{OH}^{-}$ & 5.6 & 30 & 0.37 & 22 & 2240 & 2460 \\
\hline & 3 & High $\mathrm{NO}_{3}^{-}$ & 5.6 & 4.1 & 0.14 & 22 & 1997 & 1920 \\
\hline \multirow[t]{2}{*}[\mathrm{Na}^{+}]{} & 4 & Average & 4.0 & 15 & 0.14 & 22 & 2840 & 3690 \\
\hline & 5 & Average & 7.0 & 15 & 0.14 & 22 & 1560 & 1540 \\
\hline \multirow[t]{2}{*}[K^{+}]{} & 6 & Average & 5.6 & 1.5 & 0.14 & 22 & 2260 & 2440 \\
\hline & 7 & Average & 5.6 & 150 & 0.14 & 22 & 1350 & 1370 \\
\hline \multirow[t]{3}{*}[\mathrm{Cs}+]{} & 8 & Average & 5.6 & 15 & 0.001 & 22 & 2530 & 2360 \\
\hline & 9 & Average & 5.6 & 15 & 0.01 & 22 & 2540 & 2350 \\
\hline & 10 & Average & 5.6 & 15 & 1.0 & 22 & 1700 & 1490 \\
\hline Temperature & 11 & Average & 5.6 & 15 & 0.14 & 45 & 800 & 1450 \\
\hline
\end{tabular}

*Measured at SRTC on IONSIV® IE-911,Batch 2. Predictions based on Texas A\&M K model (Ref. 4). Concentrations listed are at start of test. 


\section{Column Tests}

Column tests at different feed rates measured kinetic aspects of cesium absorption on engineered CST particles. Table VI lists the details of the three column runs. Figure 1 shows the cesium breakthrough curves for the three experiments. The figure includes predictions of column performance provided by Professor R. G. Anthony of Texas A\&M (Appendix B) prior to the tests. The following summarize differences between the predicted and observed cesium breakthrough curves.

- Column performance generally matched predictions in the intermediate and fast column runs.

- Columns performance prior to $50 \%$ breakthrough was slightly better than predicted.

- In the fast column run, performance after $50 \%$ breakthrough was slightly poorer than predicted.

- Cesium removal greatly exceeded predictions during the early phase of the slow column run.

- $\mathrm{C} / \mathrm{C}_{\mathrm{o}}$ of $0.0025 \%$ was not reached until 300 column volumes, compared to the prediction of 103 column volumes.

The scatter in the data shown in Figure 1 comes largely from analytical variability. The column data in the intermediate and fast column runs came from inductively coupled plasma mass spectroscopy (ICP-MS). The typical reproducibility of the data is approximately $\pm 10 \%$ with sample dilution variances during preparation dominating the error. Future work should consider improvements in the dilution method or use of radioactive tracers to provide better resolution as $\mathrm{C} / \mathrm{Co}$ approaches 1 .

\section{TABLE VI. Details of Ion Exchange Column Runs}

Column size

\section{Slow Intermediate $\underline{\text { Fast }}$}

$\begin{array}{lccc}\text { Diameter }(\mathrm{cm}) & 1.50 & 1.50 & 1.43 \\ \text { Length }(\mathrm{cm}) & 10.0 & 10.0 & 11.0 \\ \text { Volume }\left(\mathrm{cm}^{3}\right) & 17.7 & 17.7 & 17.7\end{array}$

Flowrate

$\begin{array}{rlll}\text { Range (mL/min) } & 0.43-0.49 & 1.63-1.82 & 6.42-6.61 \\ \text { Average (mL/min) } & 0.47 & 1.73 & 6.53 \\ (\mathrm{CV} / \mathrm{h}) & 1.59 & 5.88 & 22.1 \\ \text { Superficial velocity } & & & \\ (\mathrm{cm} / \mathrm{min}) & 0.27 & 0.98 & 4.1\end{array}$


FIGURE 1. Cesium Breakthrough During Column Runs

Slow Column

(1.59 CV/h)

Intermediate Rate (5.8 CV/h)
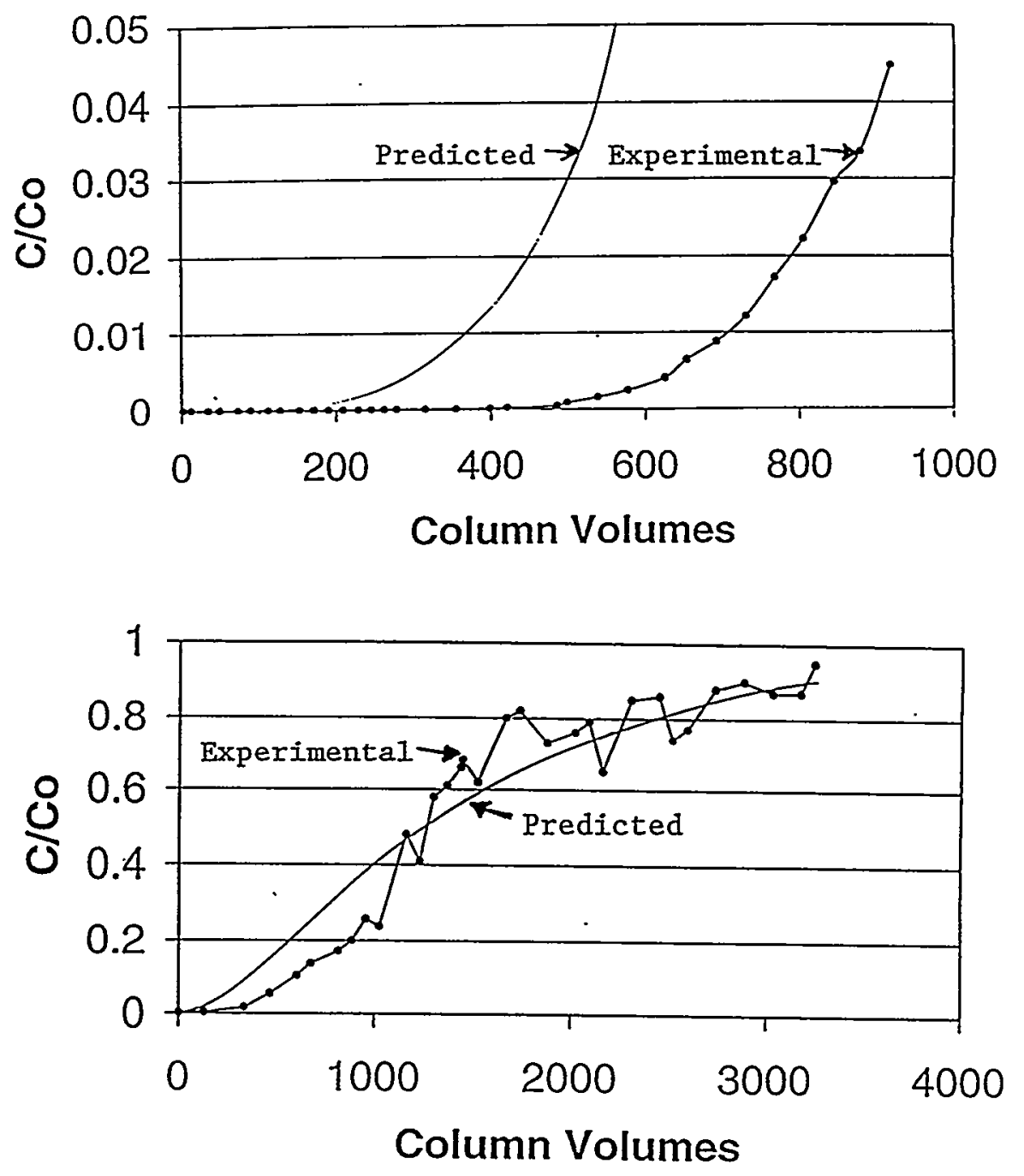

Fast Rate

(22.1 CV/h)

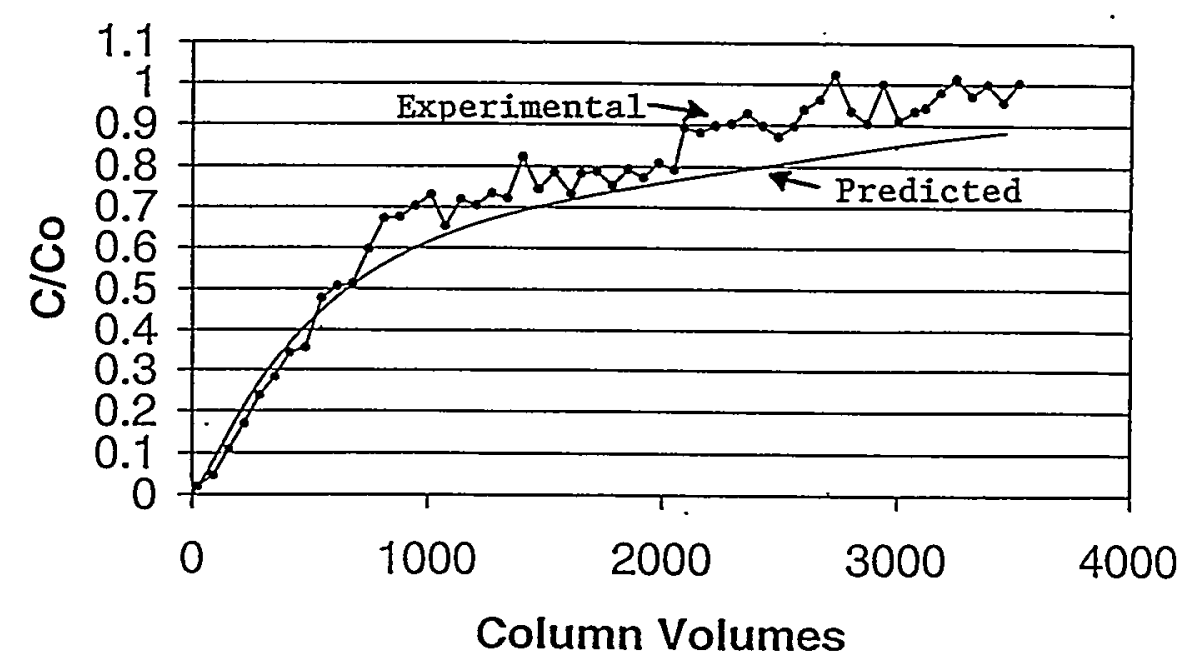




\section{ACKNLWLEDGMENTS}

The authors thank Professor R. G. Anthony of Texas A\&M University for providing a copy of the $K_{d}$ computer model and for predictions of the column runs.

\section{REFERENCES}

1. P. L. Rutland et al., "Bases, Assumptions, and Results of the Flowsheet Calculations for the Initial Eighteen Salt Disposition Alternatives", WSRC-RP-98-00166, 25 June 1998.

2. D. J. McCabe, "Crystalline Silicotitanate Examination Results (U)," WSRC-RP-941123, Rev.0, May 18, 1995.

3. D. J. McCabe, "Examination of Crystalline Silicotitanate Applicability in Removal of Cesium from SRS High Level Waste (U)," WSRC-TR-97-0016, Rev.0, April 25, 1997.

4. Z. Zheng and R. G. Anthony, "Modeling Multicomponent Ion Exchange Equilibrium Utilizing Hydrous Crystalline Silicotitanates by a Multiple Interactive Ion Exchange Site Model," Ind.Eng.Chem.Res., 36, 2427 (1997).

5. R. G. Anthony and Z. Zheng, CST Ion Exchange Version 5 (CSTIXE5), Department of Chemical Engineering, Texas A\&M University, College Station, TX. 


\title{
APPENDIX A \\ Oak Ridge National Laboratory $\mathrm{K}_{\mathrm{d}}$ Measurements
}

\section{BATCH TESTS WITH IONSIV@ IE-911 AND A SIMULANT OF THE SAVANNAH RIVER SITE "AVERAGE" SUPERNATANT: DISTRIBUTION COEFFICEINTS VS TIME}

\author{
R. D. Hunt, K. K. Anderson, J. L. Collins, and D. D. Lee
}

1. IṆTRODUCTION

The Department of Energy (DOE) is required by law to treat and safely dispose of the radioactive wastes from its nuclear weapon production activities. The primary radionuclide in the DOE liquid wastes, supernatants, is ${ }^{137} \mathrm{Cs}$. At the Savannah River Site (SRS), the In Tank Precipitation (ITP) process was selected as the baseline technology to remove ${ }^{137} \mathrm{Cs}$ from the supernatants, which are stored in underground storage tanks. In the ITP process, tetraphenylborate reacts with the water-soluble cesium to form a precipitant. The treated supernatant would then be immobilized in grout or saltstone and stored in vaults at the SRS. However, problems were encountered during the full-scale ITP processing.

These difficulties with the ITP process have led to the evaluation of alternative technologies and/or concepts to the currently configured ITP process. The High-Level Waste (HLW) Salt Disposition Team at the SRS is currently performing this assessment. After an initial screening of all potential alternatives, the Salt Disposition Team selected four primary options to evaluate further before the final down selection. Crystalline silicotitanate (CST), an inorganic ion exchanger, was chosen as one of the four alternatives. Since nearly all of the CST tests have been performed on supernatants from Hanford and Oak Ridge, the Salt Disposition Team has requested personnel at the SRS and Oak Ridge National Laboratory (ORNL) to determine the performance of the . engineered form of CST, IONSIV $\mathbb{B}$ IE-911, with actual and simulated SRS supernatants. It should be noted the UOP, the manufacturer of IONSIV® IE-911, has made the engineered form of CST in a minimum of four different batches, and some variability between the batches can be expected.

In batch tests at the SRS, IONSTV $囚 \mathrm{E}-911$ (batch 2) was used to remove ${ }^{137} \mathrm{Cs}$ from actual SRS supernatant from Tank 22H (McCabe and Oji, 1998). These SRS batch tests demonstratated that IONSIV® IE-911 (batch 2) is very effective for cesium removal with a distribution coefficient $(\mathrm{Kd})$ of $14,850 \mathrm{~mL}$. These $S R S$ results also indicate that a CST column could process 14,290 column volumes of supernatant before exhaustion. Other SRS personnel are performing batch and column tests on IONSIV® IE-911 (batch 4) with a simulant of the "average" SRS supernatant. ORNL staff members also used the simulant of the "average" SRS supernatants in the batch tests with IONSTV\& IE-911 from batches 1,3 , and 4 . 


\section{APPENDIX A (continued)}

Several of the ORNL batch tests required modifications to the CST or to the supernatant simulant. In some of the tests, the CST was used "as received". In other cases, the "treated" CST was used after the IONSIV® $\mathbb{E}-911$ was treated in $\mathrm{NaOH}$ and washed with $\mathrm{H}_{2} \mathrm{O}$. In an effort to determine the effects of fines, a portion of the CST was sieved, and CST particles between 300 and 600 microns were used in a few of the tests. Finally, $2000 \mathrm{mg} / \mathrm{L}$ of dibutylphosphate (DBP) was added to a portion of the supernatant simulant to determine the effect of DBP on the performance of CST. The Kds of IONSIV® IE911 at 24,72 , and $144 \mathrm{~h}$ were measured under the following conditions:

1) Batches 1. and 4 - "as received"

2) Batches 1, 3, and 4 - "treated".

3) Batch 4 - "as received" and "treated" - particle size of 300 to 600 microns

4) Batch 4 - "treated" - dibutylphosphate in the supernatant.

This letter report presents the ORNL results from the batch tests with the CST and the simulated SRS supernatant.

\section{SAMPLES}

\subsection{IONSIV® IE-911}

CST is a new class of inorganic ion exchangers invented and developed through a collaborative effort between Sandia National Laboratories (SNL) and Texas A\&M University. The composition of CST is proprietary, and no information on the specifics of CST synthesis or composition is known. CST is produced as a very fine powder that could be used in a batch process, but it is not suitable for use in an ion-exchange column. An engineered form, IONSIV \& IE-911, was developed by UOP, Des Plaines, Mlinois, under a Cooperative Research and Development Agreement with SNL. During the Cesium Removal Demonstration at ORNL, columns of IONSIV® IE-911 successfully removed Cs from 25,000 gal of tank supernatant (Walker et al., 1998).

\subsection{SIMULANT OF THE "AVERAGE" SRS SUPERNATANT}

The recipe for the simulant of the "average" SRS supernatant, which is shown in Attachment 1, was provided for SRS personnel. The SRS simulant was made in two batches, which were 0.5 and $1 \mathrm{~L}$. After the simulant solutions were prepared as described in Attachment 1, they were spiked with ${ }^{137} \mathrm{Cs}$ so the Cs concentration in the solutions could be monitored with gamma counter. Even though the solutions were thoroughly mixed with magnetic stir bars, a small amount of fine solids could be observed in the solutions. After samples were mixed for 5 days, they were passed through a $0.45 \mu \mathrm{m}$ high capacity in-line filter (Gelman Sciences) and combined. The density of the composite supernatant was $1.254 \mathrm{~g} / \mathrm{mL}$, which is very comparable to the density of the solutions before filtration. A portion of the composite supernatant was used to prepare 


\section{APPENDIX A (continued)}

the sample with $2000 \mathrm{mg} / \mathrm{L}$ of dibutylphosphate (DBP); $0.4058 \mathrm{~g}$ of DBP (Eastman Chemicals) was added to $200 \mathrm{~mL}$ of the composite simulant. Even though the supernatant with DBP was thoroughly mixed, an organic layer appeared on top of the solution.

\section{EXPERIMENTAL PROCEDURES}

\subsection{Water Content}

The water contents in the "treated" CST (batches 1,3, and 4) and "as received" CST (batches 1 and 4) were determined before the batch tests were initiated. Approximately $0.5 \mathrm{~g}$ of IONSIV\& IE-911 was placed into a previously weighed aluminum foil boat. After the boat and the CST were weighed with a Mettler AE200 balance, they were heated at $105^{\circ} \mathrm{C}$ until the dried CST reached a constant weight. Before the dried CST was weighed, the hot boat was placed in a desiccator until the CST had cooled to ambient temperature.

\subsection{Kd Measurements}

The Kd measurements were made using batch equilibration tests and techniques, which were previously used with IONSTVß $\mathbb{E}-911$ (Davidson et al. 1998). Duplicate samples of CST and simulant were used for each of the test conditions. Approximately $0.21 \mathrm{~g}$ (batches 1 and 4) or $0.25 \mathrm{~g}$ (batch 3) of IONSIV@ IE-911 was placed into a previously weighed 50-mL Oak Ridge centrifuge tube with a sealing cap. The goal of this step was to place $0.200 \mathrm{~g}$ of CST on a dry weight basis into each tube. After the CST and tube were weighed, approximately $40 \mathrm{~mL}$ of the supernatant simulant was added to the centrifuge tube, which was weighed after the transfer. In the initial test plan, $50 \mathrm{~mL}$ of the simulant was to be added to each tube. However, the capacity of a 50-mL Oak Ridge centrifuge tube is slightly more than $40 \mathrm{~mL}$. The volume of simulant was calculated from the specific gravity of the supernatant. The IONSIVß IE-911 and the simulated supernatant were mixed with a Labquake ${ }^{T M}$ shaker. The action of the mixer is a backand-forth rocking motion that was set to rock from $-45^{\circ}$ to $+45^{\circ}$ from the horizontal plane at -20 cycles per minute. At the end of 24,72 , and $168 \mathrm{~h}$, the tubes were reweighed to check for leakage. Then, the tubes were then centrifuged for $20 \mathrm{~min}$ at $2800 \mathrm{rpm}$ with an International Equipment Company Centra 7 tabletop centrifuge. A small aliquot ( $3 \mathrm{~mL}$ ) was removed from each sample with a glass pipet and placed into $15-\mathrm{mL}$ tube. The small aliquots were then filtered through $0.22-\mu \mathrm{m}$ nylon filters to remove any of the remaining fine particulates. The filtering system consist of a $20-\mathrm{mL}$ glass syringe, a luer-lock filter, and a short piece of tygon tubing. Samples $(0.5-1.0 \mathrm{~mL})$ of the filtered supernatants were pipetted into preweighed counting tubes for radiochemical analysis. The remaining liquid in the 15-mL tube was set aside for subsequent tests as necessary. At the completion of all of the transfers, the Oak Ridge centrifuge tube and the counting tubes were weighed. The volumes of the filtered supernatants in the $15-\mathrm{mL}$ and counting tubes were kept as 


\section{APPENDIX A (continued)}

small as possible to minimize changes to the liquid $(\mathrm{mL}) /$ solid $(\mathrm{mg})$ ratio during each test. The ${ }^{137} \mathrm{Cs}$ activity was determined using an LKB Wallac 1282 Compugamma Universal Gamma Counter. Samples were counted for $40 \mathrm{~min}$, and an empty tube was counted so the background radiation could be determined and deducted from subsequent measurements. Finally, a control test was also run. $40 \mathrm{~mL}$ of supernatant was added to a 50-mL polypropylene centrifuge tubes and mixed for 24,72 , and $168 \mathrm{~h}$. No detectable change in the ${ }^{137} \mathrm{Cs}$ activity of the simulant was noted.

\section{CALCULATIONS}

$\because$

The results of batch tests are reported as distribution coefficient (Kd) and percent removal $(\% \mathrm{R})$. These values are calculated in the following manner:

$\mathrm{Kd}=\left[\left(C_{\mathrm{i}}-C_{\mathrm{f}}\right) / C_{\mathrm{f}}\right][\mathrm{V} / \mathrm{m}]$ (units are $\mathrm{mL} / \mathrm{g}$ )

$\% \mathrm{R}=100\left[\left(C_{\mathrm{i}}-C_{\mathrm{f}}\right) / C_{\mathrm{i}}\right]$.

$C_{i}$ and $C_{\mathrm{f}}$ are the initial and final counts of ${ }^{137} \mathrm{Cs}$ per gram of supernatant, respectively. $V$ is the volume of simulant, and $m$ is the dry mass of the IONSIV® IE-911.-

\section{RESULTS}

\subsection{Water Content}

The results from the water content experiments on IONSIV® IE-911 are presented in Table 5.1. With batch 1 and batch 4 , the water contents were very comparable, and water content was not significantly affected by the treatment with $\mathrm{NaOH}$ and $\mathrm{H}_{2} \mathrm{O}$. However, the water content in the "treated" batch 3 of IONSIV@ IE-911 was significantly higher than the other batches. This observation was confirmed with a second, larger test with IONSIV® IE-911 (batch 3). It should be noted that the dried IONSIV® IE-911 quickly absorbs moisture even at ambient temperature.

Table 5.1. Water Content in Different Batches of IONSIV® IE-911

$\begin{array}{ccccc}\text { Batch number } & \text { Condition } & \text { Initial weight }(\mathrm{g}) & \text { Dry Weight }(\mathrm{g}) & \text { Water Content } \\ 1 & \text { Treated } & 0.5037 & 0.4794 & 4.82 \% \\ 1 & \text { As received } & 0.5036 & 0.4761 & 5.46 \% \\ 3 & \text { Treated } & 0.5041 & 0.4038 & 19.90 \% \\ 3 & \text { Treated } & 0.9997 & 0.7967 & 20.31 \% \\ 4 & \text { Treated } & 0.5025 & 0.4760 & 5.27 \% \\ 4 & \text { As received } & 0.5031 & 0.4790 & 4.79 \%\end{array}$




\section{APPENDIX A (continued)}

\subsection{Kd Measurements}

The $\mathrm{Kd}$ and $\% \mathrm{R}$ results from the batch equilibration tests are provided in Table 5.2. The $\mathrm{Kd}$ results were corrected for changes in the liquid $(\mathrm{mL}) /$ solids $(\mathrm{g})$ ratio during the tests. In addition, the Kd vaules are based on the "dry" weight of the CST.

Table 5.2 Batch Adsorption Data for the Removal of ${ }^{137} \mathrm{Cs}$ from the Simulant of the "Average" SRS Supernatant with IONSIV® IE-911

\begin{tabular}{|c|c|c|c|c|c|c|c|c|c|c|}
\hline \multirow[b]{2}{*}{ Batch } & \multirow[b]{2}{*}{ Condition } & \multicolumn{4}{|c|}{$\because$} & \multirow{2}{*}{$\begin{array}{c}\text { Mixing } \\
72 \mathrm{~h} \\
\mathrm{Kd} \\
(\mathrm{m} \cup \mathrm{mg})\end{array}$} & \multirow{2}{*}{$\begin{array}{l}\text { Time } \\
72 \mathrm{~h} \\
9 \mathrm{R}\end{array}$} & \multirow[b]{2}{*}{$\begin{array}{c}168 \mathrm{~h} \\
\text { Liq (mL)/ } \\
\text { Solid } \\
\text { (mg) }\end{array}$} & \multirow[b]{2}{*}{$\begin{array}{c}168 \mathrm{~h} \\
\mathrm{Kd} \\
(\mathrm{mU} / \mathrm{mg})\end{array}$} & \multirow[b]{2}{*}{$\begin{array}{c}168 \mathrm{~h} \\
9 \mathrm{R}\end{array}$} \\
\hline & & $\begin{array}{c}24 \mathrm{~h} \\
\text { Liq (mL) } \\
\text { Solid } \\
\text { (ing) }\end{array}$ & $\begin{array}{c}24 \mathrm{~h} \\
\mathrm{Kd} \\
(\mathrm{mL} / \mathrm{mg})\end{array}$ & $\begin{array}{l}24 \mathrm{~h} \\
9 \mathrm{R}\end{array}$ & $\begin{array}{l}72 \mathrm{~h} \\
\text { Liq (mL) } \\
\text { Solid } \\
\text { (mg) }\end{array}$ & & & & & \\
\hline 1 & $\begin{array}{l}\text { Trealed } \\
\text { Trealed } \\
\text { (Average) }\end{array}$ & $\begin{array}{l}202 \\
202\end{array}$ & $\begin{array}{l}434 \\
\frac{365}{400}\end{array}$ & $\begin{array}{l}68.3 \\
64.4 \\
66.4\end{array}$ & $\begin{array}{l}182 \\
188\end{array}$ & $\begin{array}{l}1377 \\
1712 \\
1545\end{array}$ & $\begin{array}{l}88.3 \\
\frac{90.1}{89.2}\end{array}$ & $\begin{array}{l}175 \\
182\end{array}$ & $\begin{array}{l}2034 \\
2029 \\
2032\end{array}$ & $\begin{array}{l}92.1 \\
21.8 \\
92.0\end{array}$ \\
\hline $\begin{array}{l}1 \\
1\end{array}$ & $\begin{array}{l}\text { As Received } \\
\text { As Received } \\
\text { (Average) }\end{array}$ & $\begin{array}{l}196 \\
206\end{array}$ & $\begin{array}{l}675 \\
596 \\
636\end{array}$ & $\begin{array}{l}77.5 \\
74.3 \\
75.9\end{array}$ & $\begin{array}{l}177 \\
179\end{array}$ & $\begin{array}{l}2073 \\
2041 \\
2051\end{array}$ & $\begin{array}{l}92.1 \\
21.9 \\
92.0\end{array}$ & $\begin{array}{l}171 \\
172\end{array}$ & $\begin{array}{l}2238 \\
\frac{2267}{2253}\end{array}$ & $\begin{array}{l}92.9 \\
23.0 \\
93.0\end{array}$ \\
\hline $\begin{array}{l}3 \\
3\end{array}$ & $\begin{array}{l}\text { Treated } \\
\text { Treated } \\
\text { (Average) }\end{array}$ & $\begin{array}{l}204 \\
203\end{array}$ & $\begin{array}{l}387 \\
327 \\
357\end{array}$ & $\begin{array}{l}65.5 \\
61.6 \\
63.6\end{array}$ & $\begin{array}{l}188 \\
182\end{array}$ & $\begin{array}{l}1153 \\
1162 \\
1158\end{array}$ & $\begin{array}{l}86.0 \\
86.5 \\
86.3\end{array}$ & $\begin{array}{l}181 \\
175\end{array}$ & $\begin{array}{l}1508 \\
\frac{1399}{1454}\end{array}$ & $\begin{array}{l}89.3 \\
88.9 \\
89.1\end{array}$ \\
\hline $\begin{array}{l}4 \\
4\end{array}$ & $\begin{array}{l}\text { Treaied } \\
\text { Trealed } \\
\text { (Avernge) }\end{array}$ & $\begin{array}{l}199 \\
202\end{array}$ & $\begin{array}{l}451 \\
363 \\
407\end{array}$ & $\begin{array}{l}69.4 \\
64.3 \\
66.9\end{array}$ & $\begin{array}{l}181 \\
180\end{array}$ & $\begin{array}{l}1234 \\
\frac{1237}{1236}\end{array}$ & $\begin{array}{l}87.2 \\
\frac{87.3}{87.3}\end{array}$ & $\begin{array}{l}175 \\
173\end{array}$ & $\begin{array}{l}1480 \\
\frac{1607}{1544}\end{array}$ & $\begin{array}{l}89.4 \\
20.3 \\
89.9\end{array}$ \\
\hline $\begin{array}{l}4 \\
4\end{array}$ & $\begin{array}{l}\text { As Received } \\
\text { As Received } \\
\text { (Avernge) }\end{array}$ & $\begin{array}{l}198 \\
206\end{array}$ & $\begin{array}{l}703 \\
592 \\
648\end{array}$ & $\begin{array}{l}78.0 \\
\frac{74.2}{76.1}\end{array}$ & $\begin{array}{l}184 \\
187\end{array}$ & $\begin{array}{r}1530 \\
841 \\
1186\end{array}$ & $\begin{array}{l}89.2 \\
81.8 \\
85.5\end{array}$ & $\begin{array}{l}177 \\
182\end{array}$ & $\begin{array}{l}2123 \\
\frac{2175}{2149}\end{array}$ & $\begin{array}{l}92.3 \\
22.3 \\
92.3\end{array}$ \\
\hline $\begin{array}{l}4 \\
4\end{array}$ & $\begin{array}{l}\text { Treated/Sieved } \\
\text { Treated/Sieved } \\
\text { (Average) }\end{array}$ & $\begin{array}{l}201 \\
201\end{array}$ & $\begin{array}{l}308 \\
337 \\
323\end{array}$ & $\begin{array}{l}61.9 \\
60.5 \\
61.2\end{array}$ & $\begin{array}{l}186 \\
185\end{array}$ & $\begin{array}{l}1065 \\
1892 \\
1479\end{array}$ & $\begin{array}{l}85.1 \\
21.1 \\
88.1\end{array}$ & $\begin{array}{l}177 \\
177\end{array}$ & $\begin{array}{l}1667 \\
\frac{1578}{1623}\end{array}$ & $\begin{array}{l}90.4 \\
89.9 \\
90.2\end{array}$ \\
\hline $\begin{array}{l}4 \\
4\end{array}$ & $\begin{array}{l}\text { As Received/ } \\
\text { Sicved } \\
\text { As Received/ }\end{array}$ & 205 & 337 & 62.2 & 178 & 1262 & 87.6 & 169 & 1818 & 91.5 \\
\hline & $\begin{array}{l}\text { Sicved } \\
\text { (Average) }\end{array}$ & 205 & $\frac{546}{442}$ & $\frac{72.7}{67.5}$ & 188 & $\frac{1709}{1486}$ & $\frac{90.1}{88.9}$ & 185 & $\frac{1881}{1850}$ & $\frac{21.1}{91.3}$ \\
\hline 4 & $\begin{array}{c}\text { Treated/ } \\
\text { Dibutylphosphat } \\
\text { c }\end{array}$ & 194 & 525 & 73.0 & 175 & 1017 & 85.3 & 168 & 1567 & 90.3 \\
\hline 4 & $\begin{array}{c}\text { Treated/ } \\
\text { Dibutylphosphat } \\
\text { c } \\
\text { (Average) }\end{array}$ & 196 & 393 & 66.7 & 173 & 1498 & 89,7 & 166 & 1490 & 20.0 \\
\hline
\end{tabular}

It is important to note that three 24-h samples, which were kept in the 15-mL tubes for several days, were filtered and counted after the results from the 24-h and 72-h tests were obtained. This delay in filtration led to a very significant improvement in the $\mathrm{Kd}$ 'results for the 24-h solutions. For the "treated" batch 3, the "treated/dibutylphosphate" batch 4, 


\section{APPENDIX A (continued)}

and the "as received/sieved" batch 4 samples, the Kds improved from 327 to 1727 (delayed filtration), from 393 to 1928, and from 337 to 2325 , respectively. The Kd values for the 24-h samples with the delay in filtration were substantially higher than the $\mathrm{Kd}$ values in the 168 - $\mathrm{h}$ tests with the same samples. This dramatic improvement in $\mathrm{Kd}$ values is most likely due to very fine CST particles. These very fine CST particles were probably produced by particle collisions during the rocking of the samples. These particles apparently remained in solution after centrifugation at $2800 \mathrm{rpm}$. Higher speed centrifugation may be needed to remove these particles after mixing. Futher tests to evaluate this effect are underway.

\section{ACKNOWLEDGMENTS}

This work was funded by the U. S. Department of Energy through the Westinghouse Savannah River Company's (WSRC) High Level Waste Management Division, and by the Office of Science and Technology's Accelerated Site Technology Deployment (ASTD) Initiative. The authors would like to thank W. L. Tamosaitis of WSRC and C. P. McGinnis of the Tanks Focus Area for their support and guidance.

\section{REEERENCES}

Davidson, D.J., J. L. Collins, K. K. Anderson, C. W. Chase, and B. Z. Egan, Removal of Cesium, Technetium, and Strontium from Tank Waste Supernatant, ORNLTM-13612, Lockheed Martin Energy Research Corporation, Oak Ridge National Laboratory, under review.

McCabe, D. J. and L. N. Oji, Distribution Coefficients for Crystalline Silicotitanate with Tank 22H, WSRC-TR-98-00197, Westinghouse Savannah River Company, 1998.

Walker, J. F. Jr., P. A. Taylor, R. L. Cummins, B. S. Evans, S. D. Heath, J. D. Hewitt, R. D. Hunt, H. L. Jennings, J. A. Kirby, D. D. Lee, S. Lewis-Lambert, S. A. Richardson, and R. F. Utrera, Cesium Removal Demonstration Utilizing Crystalline Silicotitanate Sorbent for Processing Melton Valley Storage Tank Supernate: Final Report, ORNLTM-13503, Lockheed Martin Energy Research Corporation, Oak Ridge National Laboratory, 1998. 


\title{
APPENDIX B \\ Texas A\&M Predictions of Column Performance
}

\section{Simulation of Column Test for SRS Waste Simulant}

\author{
By \\ M. E. Huckman, I. M. Latheef, \& : R.G. Anthony \\ Kinetics, Catalysis, and Reaction Engineering Laboratory. \\ Department of Chcmical Engineering, Texas A\&M University, College Station, Texas.
}

\section{Introduction}

This report details the methods and results for the simulations of three proposed SRS column experiments. The experimental column was $1.5 \mathrm{~cm}$ in diameter and $10 \mathrm{~cm}$ in length and packed with the CST UOP IONSIVTM IE-911. The operating conditions were provided in handouts from the recent meeting at Savannah River. The waste simulant is the "average" SRS waste. Three flow rates were simulated $0.25 \mathrm{~cm} / \mathrm{min}, 1.0 \mathrm{~cm} / \mathrm{min}$, and $4.0 \mathrm{~cm} / \mathrm{min}$.

An ion exchange column model, which uses a two-phase homogeneous particle balance, linear isotherm, and accounts for dispersion, was used to predicl breakthrough curves for the given flow rates. The equilibrium for the system was estimated using the equilibrium model developed by $Z$. Zheng (1996). Diffusion coefficient was estimated from batch experiments oonducted on simplificd waste solutions. Axial dispersion and film mass transfer coefficients were estimated from correlations.

\section{Equilibrium}

The equilibrium partilion coefficient or $K_{d}$ was estimated from a previously developed equilibrium model (Zheng, 1996). The waste composition was provided in a handout and was labeled the "average" simulant.

The model predicted $K_{d}$ was $1570 \mathrm{~m} / \mathrm{g}$. Savannah River data, comparing $K_{d}$ experimental to $K_{d}$ model for the SRS simulant, indicated that no correction was needed for the model predicted equilibrium valuc. 


\section{APPENDI X B (continued)}

\section{Diffusion Coefficient}

Diffusion coefficients for standard simulant were used as estimates for the actual diffusion coefficients in the SRS waste. From balch kinetic experiments, a diffusion coefficient of $2.7 \times$ $10^{-11} \mathrm{~m}^{2} / \mathrm{s}$ was estimated for IE-911-0001 granules in standard simulant. This value was also uscd to model column experiments in standard simulant and provided good fits of the column data. Thus, a value of $2.7 \times 10^{-11} \mathrm{~m}^{2} / \mathrm{s}$ was used to model the IE-911-000I behavior in the SRS solution.

\section{Modeling Methods and Results}

A two-phase homogeneous column model was used to generatc breakthrough curves for various operating conditions for the SRS waste solution. The equilibrium $K_{d}$ and diffusion coefficient were estimated as described above. The column size was given as $1.5 \mathrm{~cm}$ diamcter and $10 \mathrm{~cm}$. length. The velocities simulated were $0.25 \mathrm{~cm} / \min (1.5 \mathrm{CV} / \mathrm{h}), 1.0 \mathrm{~cm} / \mathrm{min}(6.0 \mathrm{CV} / \mathrm{h})$, and 4.0 $\mathrm{cm} / \min (24 \mathrm{CV} / \mathrm{h})$.

The attached figure shows the breakthrough curves for the three simulations under the given conditions. Table 1 lists the column volumes at which $\mathrm{DF}=40,000$ (or the outlet concentration is $0.0025 \%$ ) for each simulation.

Table 1. Column volumes at $\mathrm{DF}=40,000$ for three column simulations for SRS waste

\begin{tabular}{|c|c|}
\hline Velocity $(\mathrm{cm} / \mathrm{min})$ & CVs at DF $=40,000$ \\
\hline $0.25(1.5 \mathrm{CV} / \mathrm{h})$ & 103 \\
\hline $1.0(6.0 \mathrm{CV} / \mathrm{h})$ & 6 \\
\hline $4.0(24 \mathrm{CV} / \mathrm{h})$ & 0.2 \\
\hline
\end{tabular}


APPENDIX B (continued)

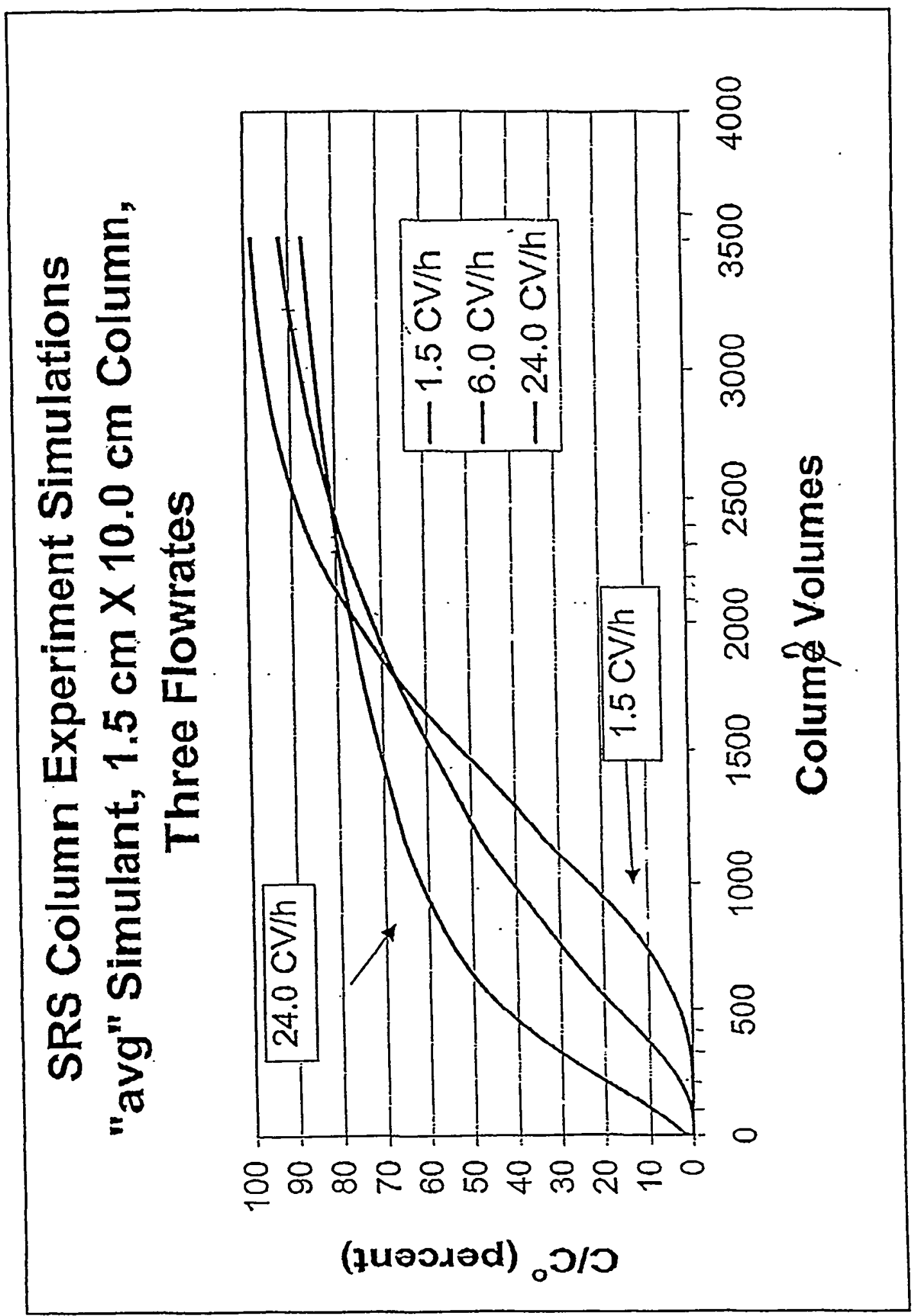




\section{APPENDIX C \\ Experimental}

\section{Preparation of Salt Solutions}

Researchers prepared simulated SRS waste solutions with the compositions shown in Table I using reagent grade chemicals. Tests used carrier free tracer Cs-137, >99\% radionuclidic purity, obtained from E. I. du Pont de Nemours \& Co., NEN Research Products, Boston, MA. Table V lists additional salt composition variations used in the $\mathrm{K}_{d}$ tests. For those solutions in which the total sodium ion concentration varied, the ratio of the anions remained fixed at the values listed in Table I. Initial cesium and potassium concentrations verification used atomic absorption spectroscopy. Personnel measured the densities of the salt solutions by weighing filled, $100-\mathrm{mL}$ or larger volumetric flasks.

\section{Crystalline Silicotitanate}

These experiments used crystalline silicotitanate in the engineered form, IONSIV® IE911, manufactured by UOP LLC., Molecular Sieves Division, Des Plaines, IL. Lot \#99909681002 was used in the slow and medium speed column runs and in the majority of the $\mathrm{K}_{d}$ tests. Lot \#99909681004 was used in the fast column run and in a few $\mathrm{K}_{d}$ tests. The particle size range for both lots was 30-60 mesh. The water content of the asreceived particles was determined by drying 0.2 gram samples to constant weight at $105^{\circ} \mathrm{C}$. The packed density of the particles was measured by filling a $25 \mathrm{~mL}$ graduated cylinder with as-received particles or with particles that had equilibrated with water in the laboratory air for two days. Table $\mathrm{C}-1$ lists the weight loss on drying and packed density for each lot.

\section{$\mathrm{K}_{\mathbf{d}}$ Tests}

Researchers used $0.1 \mathrm{~g} \mathrm{CST}$ in $25.0 \mathrm{~mL}$ of salt solution. The slurry was agitated on a shaker for 72 hours at room temperature $\left(22 \pm 2{ }^{\circ} \mathrm{C}\right)$ unless otherwise specified. Following agitation, the slurry was filtered using cellulose nitrate disposable filters $(0.2$ micron nominal pore diameter). The filtrate was analyzed by gamma spectroscopy to determine the final cesium concentration.

TABLE C-1. Properties of CST Particles

Lot\#

Weight loss on drying (wt \%)

Packed density $(\mathrm{g} / \mathrm{mL})$

As received

After air equilibration
99909681002

13.0

0.96

--
99909681004

2.7

1.01

1.08 


\section{Column Tests}

Table VI summarizes the ion exchange column dimensions and test conditions. Figure 1 shows the breakthrough curves $\left(C / C_{0}\right)$ for the three column runs. Tables $C-2, C-3$, and $C$ 4 list the data. Prior to use in column tests, the CST was pretreated in three stages. First, the particles were equilibrated with water vapor in the laboratory air for two days. Next, the particles were wetted with water, placed in a column, and flushed upflow to remove fines $(2-3 \mathrm{~L}$ of water per $20 \mathrm{~mL} \mathrm{CST}$ ). Finally, $2.2 \mathrm{M} \mathrm{NaOH}$ solution $(1 \mathrm{~L})$ was pumped in a loop through the column for 24 to 48 hours. To prepare the packed columns, the apparatus was assembled and filled with water. The slurry of flushed CST particles was added dropwise, allowing the particles to sink and disengage air bubbles. The column was settled and packed by gently tapping on the side. No change in volume of the column packing was detected during column runs. The columns were fed from 2 to 12 liter reservoirs. The spent feed solution was collected, analyzed for potassium and cesium, replenished with cesium, and reused. Flowrates were determined each time the feed solution was replaced.

\section{Analytical Methods}

Analytical Development Section of SRTC performed the following analyses.

Potassium ion concentrations on aqueous samples were measured by flame atomic absorption using a Varian SpectrAA-400 spectrometer. Each sample was diluted in a suppressant solution of cesium. The method is described in Manual L16.1, Procedure \#ADS-1549.

Cold cesium concentrations were measured by Inductively Coupled Plasma Mass Spectroscopy (ICP-MS) using a VG Elemental PQ2 instrument. Samples were diluted $1000 \mathrm{X}$ and acidified to a $\mathrm{pH}<2$ using $0.6 \mathrm{wt} \%$ nitric acid. The method is described in Manual L16.1, Procedure \#ADS-1553.

Tracer Cs-137 was measured by gamma spectroscopy counting methods using sample volumes ranging up to $10 \mathrm{~mL}$ and counting periods of up to 60 minutes. A high-purity germanium gamma spectroscopy system operated through a Canberra Genie PC software interface was used for the analysis. The method is described in Manual L16.1, Procedure \#ADS-2420. 
TABLE C-2 Data from Slow Column Run

\begin{tabular}{|c|c|c|c|c|c|c|c|c|c|c|c|c|}
\hline Date & Time & $\frac{\text { Elapsed }}{\text { Time (hr) }}$ & Total & Column & Rate & Cs-137 & $K(A A)$ & $\mathrm{C} / \mathrm{Co}(\mathrm{Cs})$ & & Cs-137 & Cs & $\mathrm{K}$ \\
\hline & & Time (hr) & Volume (느) & Volumes & $(m L / h)$ & $\mathrm{d} / \mathrm{m} / \mathrm{ml}$ & $\mathrm{mg} / \mathrm{h}$ & (\%) & & $\mathrm{d} / \mathrm{m} / \mathrm{mL}$ & (mgh) & (mg/L) \\
\hline 1-Sep & $9: 24$ & 0 & 0 & 0 & 28.4 & & & & New feed & $3.51 E+05$ & 17.9 & 534 \\
\hline & 11:02 & 1.6 & 0.045 & 2.5 & & 5.4 & 45.4 & 0.0015 & & & & \\
\hline & $16: 45$ & 7.4 & 0.21 & 11.9 & & 3.8 & 537 & 0.0011 & & & & \\
\hline 2-Sep & $6: 45$ & 21.4 & 0.608 & 34.3 & & 0.7 & 532 & 0.0002 & & & & \\
\hline & $16: 46$ & 30.4 & 0.863 & 48.8 & & $<3.5$ & 508 & $<.001$ & & & & \\
\hline 3-Sep & $6: 47$ & 45.4 & $1.28 \overline{9}$ & 72.8 & & $<\overline{3.5}$ & 533 & $<.001$ & & & & \\
\hline & $16: 54$ & 55.5 & 1.576 & 89.1 & & 12 & 522 & 0.0034 & & & & \\
\hline 4-Sep & $6: 46$ & 69.4 & 1.971 & 111.4 & 28.4 & $<2.6$ & 654 & $<.001$ & & & & \\
\hline & $16: 45$ & 79.4 & 2.256 & 127.5 & 28.5 & $<2.0$ & 603 & $<.001$ & & & & \\
\hline 5-Sep & $7: 52$ & 94.5 & 2.686 & $151 . \overline{8}$ & & $<1.9$ & 589 & $<.001$ & & & & \\
\hline & $19: 29$ & 106.2 & 3.02 & 170.6 & 28.5 & $<2.4$ & 592 & $<.001$ & & & & \\
\hline 6-Sep & $7: 34$ & 118.2 & 3.355 & 189.5 & 27.9 & $<2.9$ & 578 & $<.001$ & & & & \\
\hline & $19: 38$ & 130.2 & 3.69 & 208.5 & & $<2.6$ & 589 & $<.001$ & & & & \\
\hline 7-Sep & $8: 18$ & 142.9 & 4.044 & 228.5 & 279 & 1.3 & 581 & 0.0004 & & & & \\
\hline & $19: 55$ & 154.5 & 4.341 & 245.3 & 25.6 & 2.3 & 567 & 0.0007 & New feed & $3.24 E+05$ & 19.9 & 485 \\
\hline 8-Sep & $7: 46$ & 166.4 & 4.646 & 262.5 & 26.2 & $<3.2$ & 696 & $<.001$ & & & 20.1 & 595 \\
\hline & $16: 46$ & 175.4 & 4.933 & 278.7 & & $<7$ & & $<.002$ & & & & \\
\hline 9-Sep & $7: 46$ & 191.4 & 5.593 & 316 & 29.1 & 5.1 & 614 & 0.0016 & & & & \\
\hline 10-Sep & $7: 30$ & 214.1 & 6.291 & 355.4 & & 9.4 & 609 & 0.0029 & & & & \\
\hline 11-Sep & $9: 20$ & 240 & 7.051 & 398.4 & 29.4 & 36.4 & 662 & 0.011 & & & & \\
\hline 12-Sep & $7: 55$ & 263.5 & 7.447 & 420.7 & & 70 & 592 & 0.022 & & & & \\
\hline 13-Sep & $7: 30$ & 287.1 & 8.599 & 485.8 & & 148 & 595 & 0.046 & & & & \\
\hline 14-Sep & $7: 20$ & 311 & 8.831 & 498.9 & 29.2 & 277 & 581 & 0.085 & & & & \\
\hline 15-Sep & $7: 30$ & 335.1 & 9.534 & 538.6 & & 529 & & 0.163 & & & & \\
\hline 16-Sep & $7: 32$ & 359.2 & 10.219 & 577.3 & 29.1 & 829 & & 0.256 & New feed & $3.68 E+05$ & 17.7 & \\
\hline 17-Sep & $13: 35$ & 389.2 & 11.066 & 625.2 & 28.2 & 1498 & & 0.416 & & & & \\
\hline 18.Sep & $7: 22$ & 407 & 11.567 & 653.5 & & 2308 & & 0.641 & & & & \\
\hline 19-Sep & $7: 50$ & 431.5 & 12.257 & 692.4 & 27.9 & 3149 & & 0.875 & & & & \\
\hline 20-Sep & 8.03 & 455.7 & 12.933 & 730.7 & & 4393 & & 1.220 & & & & \\
\hline 21-Sep & $7: 20$ & .479 & 13.59 & 767.8 & 27.91 & 6198 & & 1.722 & & & & \\
\hline 22-Sep & $7: 15$ & 502.9 & 14.257 & 805.5 & 27.9 & 7998 & & 2.222 & & & & \\
\hline 23-Sep & $8: 50$ & 528.5 & 14.971 & 845.8 & 27.9 & 10646 & & 2.957 & & & & \\
\hline 24-Sep & $6: 41$ & 550.4 & 15.561 & 879.2 & 26.96 & 12118 & & 3.366 & & & & \\
\hline 25-Sep & $8: 07$ & 575.8 & 16.246 & 917.9 & 26.96 & 16039 & & 4.455 & & & & \\
\hline
\end{tabular}


TABLE C-3. Data from Intermediate Column Run

\begin{tabular}{|c|c|c|c|c|c|c|c|c|c|c|}
\hline Date & Tlme & Elapsed & Total & Column & Rate & Cs & C/Co) & & Cs & $\mathrm{K}$ \\
\hline & & Time (h) & Volume (L) & Volumes & $(\mathrm{mL} / \mathrm{m})$ & (mg/L) & & & (mg/L) & (mg/L) \\
\hline \multirow[t]{2}{*}{ 27-Aug } & $10: 37$ & 0 & 0.000 & 0.0 & & 0.03 & 0.002 & Initial feed & $19.4,18.81$ & 540,559 \\
\hline & $22: 32$ & 11.9 & 1.164 & 65.8 & & & & & & \\
\hline \multirow[t]{2}{*}{ 2B-Aug } & $10: 27$ & 23.8 & 2.328 & 131.5 & 1.63 & 0.06 & 0.003 & & & \\
\hline & $22: 22$ & 35.7 & 4.741 & 267.9 & & & & & & \\
\hline \multirow[t]{2}{*}{ 29.Aug } & $10: 17$ & 47.7 & 5.958 & 336.6 & 1.69 & 0.29 & 0.015 & & & \\
\hline & $22: 12$ & 59.6 & 7.129 & 402.8 & & & & & & \\
\hline \multirow[t]{2}{*}{ 30-Aug } & $10: 07$ & 71.5 & 8.300 & 468.9 & 1.64 & 0.99 & 0.052 & & & \\
\hline & $22: 02$ & 83.4 & 9.513 & 537.5 & & & & & & \\
\hline \multirow[t]{2}{*}{ 31-Aug } & $9: 57$ & 95.3 & 10.727 & 606.1 & 1.7 & 1.92 & 0.101 & & & \\
\hline & $22: 07$ & 107.5 & 11.979 & 676.8 & & 2.6 & 0.135 & New feed & $24.4,17.01$ & 511 \\
\hline \multirow[t]{2}{*}{ 1-Sep } & $10: 07$ & 119.5 & 13.210 & 746.3 & 1.71 & & & & & \\
\hline & $22: 07$ & 131.5 & 14.441 & 815.9 & & 3.5 & 0.17 & & & \\
\hline \multirow[t]{2}{*}{ 2-Sep } & $10: 07$ & 143.5 & 15.673 & 885.5 & 1.71 & 4.1 & 0.20 & & & \\
\hline & $22: 07$ & 155.5 & 16.904 & 955.0 & & 5.3 & 0.26 & & & \\
\hline \multirow[t]{2}{*}{ 3-Sep } & $10: 07$ & 167.5 & 18.135 & 1024.6 & 1.71 & 5.0 & 0.24 & & & \\
\hline & $22: 07$ & 179.5 & 19.366 & 1094.1 & & & & & & \\
\hline \multirow[t]{2}{*}{ 4-Sep } & $10: 07$ & 191.5 & 20.597 & 1163.7 & 1.71 & 10.0 & 0.48 & & & \\
\hline & $22: 07$ & 203.5 & 21.836 & 1233.7 & & 8.5 & 0.41 & New feed & $16.9,15.9,15.6$ & 579 \\
\hline \multirow[t]{2}{*}{ 5-Sep } & $10: 07$ & 215.5 & 23.074 & 1303.6 & 1.72 & 9.3 & 0.58 & & & \\
\hline & $22: 07$ & 227.5 & 24.305 & 1373.2 & & 9.7 & 0.61 & & & $\cdot$ \\
\hline \multirow[t]{2}{*}{ 6-Sep } & $10: 07$ & 239.5 & 25.537 & 1442.7 & 1.71 & 10.5 & 0.66 & & & \\
\hline & $22: 07$ & 251.5 & 25.660 & 1449.7 & & 10.9 & 0.68 & & & \\
\hline \multirow[t]{2}{*}{ 7-Sep } & $10: 07$ & 263.5 & 25.784 & 1456.7 & 0.172 & & & & & \\
\hline & $22: 07$ & 275.5 & 27.023 & 1526.7 & & 10.0 & 0.62 & & & \\
\hline \multirow[t]{2}{*}{ 8-Sep } & $10: 07$ & 287.5 & 28.261 & 1596.7 & 1.72 & & & & & \\
\hline & $22: 07$ & 299.5 & 29.507 & 1667.0 & & 12.8 & 0.80 & & & \\
\hline \multirow[t]{2}{*}{ 9-Sep } & $10: 07$ & 311.5 & 30.752 & 1737.4 & 1.73 & 13.1 & 0.82 & & & \\
\hline & $22: 07$ & 323.5 & 32.005 & 1808.2 & & & & New feed & $19.6,19.5$ & 522 \\
\hline \multirow[t]{2}{*}{ 10-Sep } & $10: 07$ & 335.5 & 33.258 & 1879.0 & 1.74 & 14.3 & 0.73 & & & \\
\hline & $22: 07$ & 347.5 & 34.511 & 1949.8 & & & & & & \\
\hline \multirow[t]{2}{*}{ 11-Sep } & $10: 07$ & 359.5 & 35.763 & 2020.5 & 1.74 & 14.9 & 0.76 & & & \\
\hline & $22: 07$ & 371.5 & 37.009 & 2090.9 & & 15.5 & 0.79 & New feed & 19.5 & \\
\hline \multirow[t]{2}{*}{ 12-Sep } & $.10: 07$ & 383.5 & 38.255 & 2161.3 & 1.73 & 12.7 & 0.65 & & & \\
\hline & $22: 07$ & 395.5 & 39.522 & 2232.9 & & & & & & \\
\hline \multirow[t]{2}{*}{ 13-Sep } & $10: 07$ & 407.5 & 40.789 & 2304.5 & 1.76 & 16.6 & 0.85 & & & \\
\hline & 22:07 & 419.5 & 42.049 & 2375.7 & & & & & & \\
\hline \multirow[t]{2}{*}{ 14-Sep } & $10: 07$ & 431.5 & 43.309 & 2446.8 & 1.75 & 16.8 & 0.86 & & & \\
\hline & $22: 07$ & 443.5 & 44.598 & 2519.7 & & 14.4 & 0.74 & & & \\
\hline 15-Sep & $10: 07$ & 455.5 & 45.887 & 2592.5 & 1.79 & 15.0 & 0.77 & & & \\
\hline & $22: 07$ & 467.5 & 47.161 & 2664.5 & & & & New feed & 17.1 & \\
\hline 16-Sep & $10: 07$ & 479.5 & 48.435 & 2736.5 & 1.77 & 15.0 & 0.88 & & & \\
\hline & 22:07 & 491.5 & 49.731 & 2809.7 & & & & & & \\
\hline 17-sep & $10: 07$ & 503.5 & 51.027 & 2882.9 & 1.8 & 15.4 & 0.90 & & & \\
\hline & $22: 07$ & 515.5 & 52.338 & 2956.9 & & & & & & \\
\hline 18-Sep & $10: 07$ & 527.5 & 53.648 & 3031.0 & 1.82 & 14.9 & 0.87 & & & \\
\hline & & 539.5 & 54.908 & 3102.2 & & & & & & \\
\hline $19 \mathrm{Set}$ & $10: 07$ & 551.5 & 56.168 & 3173.3 & 1.75 & 14.8 & 0.87 & & & \\
\hline & $22: 07$ & 563.5 & 57.428 & 3244.5 & & 16.2 & 0.95 & & & \\
\hline
\end{tabular}


TABLE C-4. Data from Fast Column Run

\begin{tabular}{|c|c|c|c|c|c|c|c|c|c|c|}
\hline Date & $\pi i m e$ & Elapsed & Total & Column & Rate & Cs & cro & & $C_{8}$ & \\
\hline & & $\pi \mathrm{me}(\mathrm{hr})$ & Volume (L) & Volumes & $(m L M)$ & $(\mathrm{mgl})$ & & & (mgl) & \\
\hline \multirow[t]{6}{*}{ 21-Sep } & $8: 05$ & 0 & 0 & o & 6.42 & & & New loed & 17.71 & \\
\hline & $9: 06$ & 1.02 & 0.393 & 22.2 & & 0.342 & 0.0189 & Control & 18.39 & \\
\hline & 12:06 & 4.02 & 1.549 & 87.5 & & 0.854 & 0.0473 & & & \\
\hline & 15:06 & 7.02 & 2.704 & 152.8 & & 1.874 & 0.1094 & & & \\
\hline & 18:06 & 10.02 & 3.860 & 218.1 & & 3.072 & 0.1702 & & & \\
\hline & 21:06 & 13.02 & 5.015 & 283.4 & & 4.285 & 0.2374 & & & \\
\hline \multirow[t]{7}{*}{ 22-Sep } & $0: 06$ & 16.02 & 6.171 & 348.6 & & 5.091 & 0.2820 & & & \\
\hline & $3: 06$ & 19.02 & 7.327 & 413.9 & & 6.186 & 0.3427 & & & \\
\hline & $6: 06$ & 22.02 & 8.482 & 479.2 & 6.42 & 6.412 & 0.3552 & & & \\
\hline & $9: 18$ & 25.2 & 9.712 & 548.7 & 6.53 & 7.07 & 0.4777 & New leed & 14.8 & \\
\hline & 12:18 & 28.2 & 10.888 & 615.1 & & 7.49 & 0.5061 & Control & 16.9 & \\
\hline & 3:18 & 31.2 & 12.063 & 681.5 & & 7.59 & 0.5128 & & & \\
\hline & $6: 18$ & 34.2 & 13.238 & 747.9 & & 8.84 & 0.5973 & & & \\
\hline \multirow[t]{8}{*}{ 23-Sep } & $9: 18$ & 37.2 & 14.414 & 814.3 & & 9.94 & 0.6716 & & & \\
\hline & $0: 18$ & 40.2 & 15.589 & 880.7 & & 10 & 0.6757 & & & \\
\hline & $3: 18$ & 43.2 & 16.765 & $\because 947.2$ & & 10.4 & 0.7027 & & & \\
\hline & $6: 18$ & 46.2 & 17.940 & 1013.6 & 6.53 & 10.8 & 0.7297 & & & \\
\hline & 9:18 & 49.2 & 19.029 & 1.075 .1 & 6.56 & 11.4 & 0.6533 & Naw food & $16.6,18.3$ & \\
\hline & $12: 18$ & 52.2 & 20.210 & 1.141 .8 & & 13.3 & 0.7181 & Control & 17.3 & \\
\hline & 3:18 & 55.2 & 21.391 & 1.208 .5 & & 12.3 & 0.7049 & & & \\
\hline & $6: 18$ & 58.2 & 22.571 & 1.275 .2 & & 12.8 & 0.7335 & & & \\
\hline \multirow[t]{8}{*}{ 24-Sep } & $9: 18$ & 61.2 & 23.752 & 1.341 .9 & & 12.6 & 0.7221 & & & \\
\hline & $0: 18$ & 64.2 & 24.933 & 1.408 .6 & & 15.2 & 0.8223 & & & \\
\hline & $3: 18$ & 67.2 & 26.114 & 1.475 .4 & & 13 & 0.7450 & & & \\
\hline & $6: 18$ & 70.2 & 27.295 & $1,542.1$ & 6.56 & 13.7 & 0.7851 & & & \\
\hline & $9: 18$ & 73.2 & 28.525 & 1611.6 & 6.46 & 14.7 & 0.7332 & Naw leed & $20.5,19.6$ & \\
\hline & 12:18 & 75.2 & 29.300 & 1655.4 & & 15.7 & 0.7830 & Control & 18.8 & \\
\hline & 3:18 & 78.2 & 30.463 & 1721.1 & & 15.8 & 0.7880 & & & \\
\hline & $6: 18$ & 81.2 & 31.626 & 1786.8 & & 15.1 & 0.7531 & & & \\
\hline \multirow[t]{8}{*}{ 25-Sep } & $9: 18$ & 84.2 & 32.789 & 1852.5 & & 15.9 & 0.7930 & & & \\
\hline & $0: 18$ & 87.2 & 33.952 & 1918.2 & & 15.5 & 0.7731 & & & \\
\hline & $3: 18$ & 90.2 & 35.114 & 1983.9 & & 16.2 & 0.8080 & & & \\
\hline & $6: 18$ & 93.2 & 36.277 & 2049.6 & 6.46 & 15.9 & 0.7930 & & & \\
\hline & $9: 18$ & 96.2 & 37.048 & 2093.1 & 6.53 & 18.2 & 0.8922 & New foed & 20.3 & \\
\hline & $12: 18$ & 99.2 & 38.223 & 2159.5 & & 18.0 & 0.8824 & Control & 19.2 & \\
\hline & $3: 18$ & 102.2 & 39.399 & 2225.9 & & 18.3 & 0.8971 & & & \\
\hline & $6: 18$ & 105.2 & 40.574 & 2292.3 & & 18.4 & 0.9020 & & & \\
\hline \multirow[t]{8}{*}{ 26-Sep } & $9: 18$ & 108.2 & $41 . \overline{749}$ & 2358.7 & & 18.9 & 0.9265 & & & \\
\hline & $0: 18$ & 111.2 & 42.925 & 2425.1 & & 18.3 & 0.8971 & & & \\
\hline & $3: 18$ & 114.2 & 44.100 & 2491.5 & & 17.8 & 0.8725 & & & \\
\hline & $6: 18$ & 117.2 & 45.276 & 2557.9 & 6.53 & 18.3 & 0.8971 & & & \\
\hline & $9: 18$ & 120.2 & 46.062 & 2602.4 & 6.61 & 19.5 & 0.9375 & New foed & 20.8 & \\
\hline & $12: 18$ & 123.2 & 47.252 & 2669.6 & & 20.0 & 0.9615 & Control & 20.2 & \\
\hline & $3: 18$ & 126.2 & 48.442 & 2736.8 & & 21.3 & 1.0240 & & & \\
\hline & $6: 18$ & 129.2 & 49.632 & 2804.1 & & 19.4 & 0.9327 & & & \\
\hline \multirow[t]{8}{*}{ 27.Sep } & $9: 18$ & 132.2 & 50.822 & 2871.3 & & 18.8 & 0.9038 & & & \\
\hline & $0: 18$ & 135.2 & 52.011 & 2938.5 & & 20.8 & 1.0000 & & & \\
\hline & $3: 18$ & 138.2 & 53.201 & 3005.7 & & 19.0 & 0.9135 & & & \\
\hline & $6: 18$ & 141.2 & 54.391 & 3072.9 & 6.61 & 19.4 & 0.9327 & New Feed & 20.6 & \\
\hline & $9: 18$ & 144.2 & 55.177 & 3117.4 & 6.61 & 19.4 & 0.9417 & Control & 20.5 & \\
\hline & $12: 18$ & 147.2 & 56.367 & 3184.6 & & 20.2 & 0.9806 & & & \\
\hline & $3: 18$ & 150.2 & 57557 & 3251.8 & & 20.9 & 1.0146 & & & \\
\hline & $6: 18$ & 153.2 & 58.747 & 3319.0 & & 20.0 & 0.9709 & & & \\
\hline \multirow[t]{4}{*}{$27-\mathrm{Seg}$} & 9:18 & 156.2 & 59.937 & 3386.2 & & 20.6 & 1.0000 & & & \\
\hline & $0: 18$ & 159.2 & 61.126 & 3453.5 & & 19.7 & 0.9563 & & . & \\
\hline & $3: 18$ & 162.2 & 62.316 & 3520.7 & 6.61 & 20.7 & 1.0049 & & & \\
\hline & & & & & & & & & & \\
\hline
\end{tabular}


CC: G. E. Abell, 704-3N

B. N. Attaway, 773-A

J. L. Barnes, 704-3N

M. J. Barnes, 773-A

S. B. Beck, 704-3N

N. E. Bibler, 773-A

J. D. Carlson, 703-H

J. T: Carter, 704-25S

G. L. Cauthen, 241-119H

W. C. Clark, 704-56H

C. L. Crầwford, 773-41A

Dr. E. Cussler, 704-3N

N. R. Davis, 703-H

R. A. Dimenna, 773-42A

D. P. Diprete, 773-42A

L. O. Dworjanyn, 779-2A

R. E. Eibling, 704-T

H. H. Elder, 704-S

S. D. Fink, 773-A

F. Fondeur, 773-62A

J. R. Fowler, 704-3N

M. W. Geeting, 773-24A

J. C. Griffin, 773-A

T. Hang, 773-42A

D. T. Hobbs, 773-A

E. W. Holtzscheiter, 773-A

P. I. Hudson, $704-3 \mathrm{~N}$

R. A. Jacobs, 704-3N

M. D. Johnson, 703-H

M. T. Keefer, 241-153H

W. D. King, 772-42A

P. S. Kirkland, 703-46A

E. J. Kosiancic, 704-3N

L. F. Landon, 704-T

B. L. Lewis, 703-H
T. J. Lex, 703-H

P. E. Lowe, 773-41A

D. J. McCabe, 773-42A

J. W. McCollough, 703-H

M. S.Miller, 704-56H

T. M. Monahon, 703-H

J. P. Morin, 703-H

E. T. Murphy, 704-3N

C. A. Nash, 773-42A

L. M. Nelson, 773-43A

L. M. Papouchado, 773-A

P. K. Paul, 773-42A .

R. A. Peterson, 773-A

S. F. Piccolo, 704-3N

M. R. Poirier, 676-T

M. J. Polochko, 773-A

K. J. Rueter, 706-S

P. L. Rutland, 704-196N

R. H. Spires, 703-H

W. E. Stevens, 773-A

P. C. Suggs, 704-3N

R. F. Swingle, 773-A

W. L. Tamosaitis, 773-A

G. A. Taylor, $704-196 \mathrm{~N}$

L. L. Tovo, 773-A

W. B. VanPelt, 676-1T

D. D. Walker, 773-A

Dr. J. Watson, 704-3N

W. R. Wilmarth, 773-42A

G. T. Wright, 773-A

J. E. Young, 773-A

TIM, 703-43A

WPTS Files, 773-A, c/o S. Poston, 773-A

ITP files, c/o A. G. Wiest, 241-119H 